\title{
Blood electrolytes changes in peritonitis of cattle
}

\author{
Mohammad Reza Mokhber Dezfouli • Samad Lotfollahzadeh • Sirous Sadeghian • \\ Gholam Ali Kojouri • Zohre Eftekhari • Farshid Khadivar • Ali Bashiri
}

Received: 10 August 2010 /Accepted: 1 August 2011 /Published online: 18 August 2011

(C) The Author(s) 2011. This article is published with open access at Springerlink.com

\begin{abstract}
Peritonitis is an inflammation of the peritoneal cavity and is one of the main causes of animal deaths. It has been reported that many diseases such as peritonitis cause electrolyte imbalance in the body. The present study has been conducted to evaluate the serum electrolyte concentration in cattle with peritonitis. In order to perform this study, 45 cattle with peritonitis were selected in the Karaj area, and 20 healthy cattle were used as the control group. After diagnosis of peritonitis in the infected cattle, 10-ml blood samples were taken from the jugular vein, the concentrations of calcium, phosphorus, magnesium, and chloride were estimated using the spectrophotometric method, and sodium and potassium concentrations were assessed by a flame photometer device. The results showed that the concentrations of calcium, magnesium, sodium, potassium, and chloride in cattle affected with peritonitis were reduced compared with the control group, but the differences were not statistically significant. The concentration of phosphorus in the peritonitis-infected cattle was significantly higher than in the healthy cattle. On the basis of the results of the present study, it can be
\end{abstract}

M. R. Mokhber Dezfouli · S. Lotfollahzadeh · S. Sadeghian $(\bowtie) \cdot$

Z. Eftekhari

Department of Clinical Sciences, Faculty of Veterinary Medicine,

Tehran University,

Tehran, Iran

e-mail: s.sadeghianvet@yahoo.com

F. Khadivar · A. Bashiri

Faculty of Veterinary Medicine, Tehran University,

Tehran, Iran

G. A. Kojouri

Department of Clinical Sciences, Faculty of Veterinary Medicine, Shahrekord University,

Shahrekord, Iran concluded that inflammation of the peritoneal cavity in cattle causes blood electrolyte deterioration, and more attention needs to be focused on this factor in the treatment of infected animals.

Keywords Cattle $\cdot$ Peritonitis $\cdot$ Electrolytes $\cdot$ Karaj

\section{Introduction}

Internal adhesions of the abdominal cavity resulting from peritonitis are one of the main sources of disease and death in dairy cattle (Cornelis et al. 2009). Peritonitis, inflammation of the peritoneal cavity, may be localized or generalized and may be chronic or acute (Andrews et al. 2004). Pathogenesis of peritonitis is correlated with conditions such as severe inflammation, adhesion, and spoilage of tissue (Herzog et al. 2004). Peritonitis is a very common syndrome reported by many countries and might be a result of disorganization of small farms, nonstandard management, and unhealthy nutrition. As it causes an extreme reduction in milk production and an increasing number of deaths in cattle, peritonitis is financially a very important disease (Radostits et al. 2007). Peritonitis usually occurs along with other diseases often due to traumatic reticulitis (Andrews et al. 2004). Escherichia coli is the most common cause of peritoneum bacterial infection (Demling et al. 1993). Peritonitis often occurs in adult dairy cattle but rarely happens in young cattle, beef, or feedlot bovine (Radostits et al. 2007). Maintaining electrolytes in appropriate amounts is essential for normal biochemical and physiological functions of the body. Electrolytes are distributed in body fluids and play a key role in all parts of animal life (Kaneko et al. 2008). Many diseases (such as peritonitis) cause a change in fluids and electrolyte balance 
(Radostits et al. 2007; Smith 2009). The aim of the present study is to assess the serum levels of calcium (Ca), phosphorus $(\mathrm{P})$, magnesium $(\mathrm{Mg})$, sodium $(\mathrm{Na})$, potassium $(\mathrm{K})$, and chloride $(\mathrm{Cl})$ in cattle with peritonitis and compare these with those of healthy cattle.

\section{Materials and methods}

\section{Study design}

After thorough clinical examination and paraclinical confirmation, 45 cattle suspected of suffering from peritonitis in the Karaj area (in the center of Iran near the capital, Tehran) were selected in this research. Twenty normal and healthy cattle without peritonitis infection were selected as control group. Infected cattle were mostly in the age range of 2-6 years and were reared traditionally. The clinical signs of infected cattle were observed and recorded. Peritonitis in infected cattle was confirmed by synthesis of the peritoneal cavity with properly disinfected procedures (Andrews et al. 2004; Radostits et al. 2007; Smith 2009). The obtained peritoneal fluid in the infected animals was a dark yellow color bubbled fluid in $84.44 \%$ and a pink fluid in $15.55 \%$. All the samples were transferred to the laboratory for bacteriologic culture and cellular analysis (Table 2).

\section{Collection of blood samples}

Two blood samples were collected from each animal by jugular vein puncture into acid-washed polyethylene tubes: one with EDTA (as an anticoagulant) for hematologic analyses and the other one without anticoagulant for biochemical (electrolytes) analyses. Samples containing EDTA were transferred to the laboratory on ice. Blood samples for biochemical analysis were allowed to clot, and serum was extracted by centrifugation at $2,000 \times g$ for $10 \mathrm{~min}$ within $2 \mathrm{~h}$ after collection. Sera were stored at $-20^{\circ} \mathrm{C}$ for a short period until analysis.

\section{Hematologic and biochemical analysis}

Hematological parameters including white blood cell (WBC) count, total protein, and fibrinogen concentrations were measured by routine procedures (Jain 1986). WBC measurement was carried out using manual standard method (Jain 1993). Differential leukocyte counts were performed on routinely prepared Giemsa-stained blood smears using the cross-sectional technique (Jain 1993). Serum $\mathrm{Ca}, \mathrm{P}$, and $\mathrm{Mg}$ concentrations were determined by commercial reagent kits (ZiestChem Diagnostics, Tehran, Iran) using an automated autoanalyzer (Shimadzu Model
AA 6200, Tokyo, Japan); serum $\mathrm{Cl}$ concentration was determined by atomic absorption spectrophotometer. Atomic absorption was measured at $570 \mathrm{~nm}$ for $\mathrm{Ca}, 630 \mathrm{~nm}$ for $\mathrm{P}$, $520 \mathrm{~nm}$ for $\mathrm{Mg}$, and $480 \mathrm{~nm}$ for $\mathrm{Cl}$. Na and $\mathrm{K}$ values were obtained with the use of a flame photometer (Jenway, PFP 7 Clinical, Essex, England).

Statistical analysis

The SPSS package (version 15) was used for hematology and biochemical data analysis. After testing normal distributions of the data, parametric independent $t$ test was used to investigate significant differences between control and infected groups at $P<0.05$.

\section{Results}

\section{Clinical findings}

Daily clinical examinations revealed that 45 cattle had signs of peritonitis infection of variable severity. Clinical symptoms included reduction in cattle appetite $(100 \%)$, increase in body temperature $(77.77 \%)$, increased heart rate $(73.33 \%)$, increased respiratory rate $(71.11 \%)$, reduction in milk production $(97.77 \%)$, the presence of pain in the abdominal area when palpated $(93.33 \%)$, weight loss $(88.88 \%)$, and reluctance to move $(66.66 \%)$.

\section{Hematological and biochemical findings}

Mean values of blood (including hematologic and biochemical indices) and peritoneal fluid parameters in cattle with peritonitis are shown in Tables 1 and 2. As can be seen in Table 1, there is an increase in the WBC and neutrophil counts, as well as total protein and fibrinogen concentrations in the infected cattle with peritonitis. The results of the analyses for $\mathrm{Ca}, \mathrm{P}, \mathrm{Mg}, \mathrm{Na}, \mathrm{K}$, and $\mathrm{Cl}$ are shown in Table 3 . The concentrations of $\mathrm{Ca}, \mathrm{Mg}, \mathrm{Na}, \mathrm{K}$, and $\mathrm{Cl}$ in infected cattle were $8.317 \pm 1.389 \mathrm{mg} / \mathrm{dl}, 1.770 \pm 0.436 \mathrm{mg} / \mathrm{dl}$, $137.667 \pm 2.517 \mathrm{meq} / \mathrm{L}, 3.933 \pm 0.513 \mathrm{meq} / \mathrm{L}$, and $95.333 \pm$ $8.145 \mathrm{meq} / \mathrm{L}$, respectively, which are less than those of the control group, but the differences were not statistically significant $(P>0.05)$. At the same time, the phosphorus level in the infected group slightly increased $(6.533 \pm 0.968 \mathrm{mg} / \mathrm{dl})$ compared to that of the control group, but this difference was not also significant statistically $(P>0.05)$.

\section{Discussion}

Keeping electrolytes in body size and scale suitable for biochemical and physiological actions is necessary for a 
Table 1 Mean values of hematologic and serum protein and fibrinogen concentrations in cattle with peritonitis (mean \pm SD)

\begin{tabular}{|c|c|c|c|c|c|c|}
\hline Blood cell mounts & WBC & Neu. band & Neu. Seg. & Lymphocyte & Plasma protein & Fibrinogen \\
\hline Mean \pm SD & $11,476.92 \pm 8,709.87$ & $204.23 \pm 302.38$ & $7,868.30 \pm 8,097.42$ & $3,281.00 \pm 1,095.31$ & $7.23 \pm 1.25$ & $1.01 \pm 1.64$ \\
\hline Maximum & $29,200.0$ & $1,014.0$ & $25,112.0$ & $5,075.0$ & 9.80 & 6.40 \\
\hline Minimum & $2,300.0$ & 0 & 897.0 & $1,357.0$ & 6.00 & 0.30 \\
\hline
\end{tabular}

normal body. Electrolytes are distributed in body fluids and play a vital role in all stages of animal life (Kaneko et al. 2008). Most electrolytes lose their balance in digestive system disorders. There are many diseases of farm animals in which there are disturbances of body fluids (free water), electrolytes, and acid-base balance. A disturbance of the body water balance in which more fluid is lost from the body than is absorbed results in a reduction in circulating blood volume and in dehydration of the tissues. Electrolyte imbalances commonly occur because of a loss of electrolytes, shift of certain electrolytes, or relative changes in concentrations due to loss of water (Radostits et al. 2007). Calcium plays a central role in maintaining homeostasis of animals, including muscle contraction, blood coagulation, enzyme activity, neural excitability, hormone secretion, and cell adhesion, in addition to being an essential structural component of the skeleton (Capen and Rosol 1993). Calcium is also involved in the pathogenesis of metabolic diseases that disrupt the normal regulation of its balance and may result in hypercalcemia or hypocalcemia (Chew et al. 1992). Reduction in the calcium level of blood cells might occur in the dairy cows that had anorexia for a couple of days (Radostits et al. 2007). Infectious diseases that cause anorexia such as peritonitis can cause reduction in the calcium level of blood (Smith 2009). Decreased calcium concentration in cattle with peritonitis in the present study compared to the control group was due to anorexia. Phosphate is the main intracellular anion and has many metabolic functions such as muscle contraction, delivery of oxygen to tissues, bone integrity, and energy metabolism (Dennis 1996). Serum phosphorus values principally reflect current dietary intake (Whitaker et al. 1998). This could be due to differences in the chemical composition of the ingested feed. Phosphorus resumption increases during animal growth, lactation, and pregnancy (Lotscher et al. 1996; Silverstein et al. 1996). Phosphorus has a close connection with $\mathrm{Ca}$ (Radostits et al. 2007) which enhances blood $\mathrm{P}$ level due to the reaction between $\mathrm{P}$ and the $\mathrm{Ca}$ ions, as concentrations of ionized $\mathrm{Ca}$ in serum are reduced (Kaneko et al. 2008). Therefore, the reduced concentration of $\mathrm{Ca}$ in a patient's serum can be due to the band with $\mathrm{P}$ and, in this research, the level of $\mathrm{P}$ is higher in infected cattle compared to the control group, which could result from food intake containing high P. Magnesium is an essential element for animal nutrition (McDowell 1992). Hypomagnesemia is often accompanied and complicated by hypocalcemia (Smith 2009). Rumen Mg absorption may be increased by lowering the $\mathrm{pH}$ (which increases Mg solubility) and decreased by microbial sequestration (Kennedy and Bunting 1991). Plasma Mg concentration may be related to lipolysis during stress, cold, or starvation and is reduced during those situations (Rayssiguier 1984). Hypomagnesemia can also result in hypokalemia refractory to $\mathrm{K}$ supplementation (Smith 2009). Thus, in this research, the reduction of the $\mathrm{Mg}$ level in the patient group compared to the control group is due to malnutrition and anorexia resulting from peritonitis. Na has the highest number of ions in the extracellular fluid and is often responsible for maintaining the osmotic pressures of the extracellular fluid. The most common causes of hyponatremia are lack or an inadequate level of dietary sodium and decreased $\mathrm{Na}$ absorption in the intestines which is caused by enteropathy (Radostits et al. 2007). Changes in relative water content tend to produce proportional changes in plasma $\mathrm{Na}$ and $\mathrm{Cl}$ concentrations (Leaf 1962), whereas acid-based alterations are often associated with disproportionate changes in plasma $\mathrm{Cl}$ concentration (Saxton and Seldin 1996). Hyponatremia is often, but not invariably, associated with conditions that

Table 2 Biochemical and cellular analysis of peritoneal fluid of cattle with peritonitis (mean \pm SD)

\begin{tabular}{|c|c|c|c|c|c|c|c|}
\hline \multirow{2}{*}{$\begin{array}{l}\text { Cellular change } \\
\text { mounts }\end{array}$} & \multirow{2}{*}{$\begin{array}{l}\text { Total protein } \\
(\mathrm{g} / \mathrm{dl})\end{array}$} & \multirow{2}{*}{$\begin{array}{l}\text { Specific gravity } \\
\text { (SPG) }\end{array}$} & \multirow{2}{*}{$\begin{array}{l}\text { Total RBC } \\
\left(\times 10^{6} / \mu \mathrm{l}\right)\end{array}$} & \multirow{2}{*}{$\begin{array}{l}\text { Total WBC } \\
\left(\times 10^{6} / \mu 1\right)\end{array}$} & \multicolumn{3}{|c|}{ Differential leukocyte } \\
\hline & & & & & Macro. (\%) & Lym. (\%) & Neu. $(\%)$ \\
\hline Mean \pm SD & $4.12 \pm 0.8105$ & $1.027 \pm 0.0151$ & $0.1060 \pm 0.0364$ & $6.92 \pm 1.3516$ & $71.40 \pm 6.7675$ & $18.80 \pm 7.498$ & $7.80 \pm 3.1144$ \\
\hline Maximum & 5.10 & 82.00 & 0.15 & 9.10 & 1.04 & 26.00 & 12.00 \\
\hline Minimum & 3.00 & 1.01 & 0.05 & 5.50 & 64.00 & 11.00 & 5.00 \\
\hline
\end{tabular}


cause Na depletion such as vomiting, diarrhea, and excessive sweat loss. No sodium or chloride has been lost from the body, and the observed decreases in the electrolyte concentration are caused by changes in the relative water balance. Alteration in the $\mathrm{Cl}$ concentration is usually associated with similar proportional changes in the $\mathrm{Na}$ concentration as the result of changes in relative water balance (Scribner 1969; Smith 2009). A proportionate decrease in $\mathrm{Cl}$ relative to $\mathrm{Na}$ is characteristically seen in diarrhea, blood loss, and sweat (Smith 2009). Accumulation of fluids containing $\mathrm{Na}$ in body cavities or the intestinal tract is a result of peritoneal inflammation (Rose 1984) that reduces plasma content followed by a reduction in serum $\mathrm{Na}$ concentration due to kidney responses which keep the water from being excreted (Smith 2009). Some of the most common reasons responsible for the reduction in serum $\mathrm{Na}$ and $\mathrm{Cl}$ levels are peritoneal inflammation, ascites, and diarrhea (Smith 2009). Decreasing $\mathrm{Cl}$ without decreasing the proportion of $\mathrm{Na}$ can be followed by metabolic alkalosis such as abomasal torsion and vagus indigestion (Smith 2009). As is obvious in the current study, peritonitis causes a reduction in $\mathrm{Na}$ and $\mathrm{Cl}$ levels due to the inflammation process. Potassium serum level does not always reflect $\mathrm{K}$ balance but is affected by factors that change the internal balance and those that change external balance (Brobst 1986; Patrick 1997; Rose 1984). Hypokalemia may result from depletion of the body's K store or from a redistribution of $\mathrm{K}$ from the ECF into the ICF space (Brobst 1986). Changes in K concentration occur in a wide range of clinical conditions. Reduction in blood $\mathrm{K}$ level commonly occurred along with changes in food intake and absorption of $\mathrm{K}$ such as ileus, peritonitis, diarrhea, and vomiting (Smith 2009). It is known that low $\mathrm{Mg}$ levels result in low $\mathrm{K}$; thus, the decrease of $\mathrm{K}$ seen in infected cattle $(P>0.05)$ might be the result of lower Mg levels (Abdelrahman et al. 2002; Greene et al. 1983; Rude and Oldham 1990). Chronic lack of $\mathrm{K}$ in food intake can also result in a reduction in the $\mathrm{K}$ level of the blood (Aitken 1976; Dow et al. 1987). In the current study, the reduction in $\mathrm{K}$ was also caused by both the extreme loss of $\mathrm{K}$ through the digestive system on the one hand and that resulting from anorexia caused by an inflammation on the other.

\section{Conclusion}

On the basis of the results of the present study, it can be concluded that inflammation of the peritoneal cavity in cattle causes blood electrolyte deterioration and requires greater attention in the treatment of infected animals. Thus, the compounds containing the aforementioned ions must be used for treatment to balance the level of ions in blood serum in order to prevent further consequences. 
Open Access This article is distributed under the terms of the Creative Commons Attribution Noncommercial License which permits any noncommercial use, distribution, and reproduction in any medium, provided the original author(s) and source are credited.

\section{References}

Abdelrahman MM, Abo-Shehada MN, Mesanat A, Mukbel R (2002) The requirements of calcium by Awasi ewes at early lactation. S R RES 45:101-107

Aitken FC (1976) Sodium and potasium in nutrition of mammals. Technical communication no. 26, Commonwealth Bureau of Nutrition, Commonwealth Agricultural Bureaux, Farnham Royal, England

Andrews AH, Blowey RW, Boyd H, Eddy RG (eds) (2004) Bovine medicine: diseases and husbandry of cattle, second edition. Wiley-Blackwell, New York pp 849-850

Brobst D (1986) Review of the pathophysiology of alterations in potassium homeostasis. J Am Vet Med Assoc 188:1019-1025

Capen ML, Rosol TJ (1993) Hormonal control of mineral metabolism. In: Bojrab MJ (ed) Disease mechanisms in small animal surgery. Lea and Fibiger, Philadelphia, pp 841-857

Chew DJ, Nagode LA, Carothers M (1992) Disorders of calcium: hypercalcaemia and hypocalcaemia. In: DiBartola SP (ed) Fluid therapy in small animal practice. Saunders, Philadelphia, pp 116176

Cornelis JJM, Sikkink MD, Michel MPJ, Reijnen MD, Laverman P, Wim JG, Oyen MD, Harry van Goor MD (2009) Tc-99 m-PEGLiposomes target both adhesions and abscesses and their reduction by hyaluronate in rats with fecal peritoniti. J Surg Res 154:246-251

Demling R, Daryani R, Campbell C, Knox J, Youn YK (1993) The effect of acute bacterial depent peritonitis on lung and liver oxidant stress and antioxidant activity. Surgery 114:571

Dennis VW (1996) Phosphate metabolism: Contribution of different cellular compartments. Kidney Int 49:938-942

Dow SW, Fettman MJ, LeCouteur RA, Hamar DWJ (1987) Potasium depletion in cats: renal and dietary influences. J Am Vet Med Assoc 191:1569-1575

Greene LW, Webb KE, Fontenot JP (1983) Effect of potassium level on site of absorption of magnesium and other macro minerals in sheep. J Anim Sci 56:1214-1219

Herzog K, Kaske M, Bischoff C, Kehler W, Hoeltershinken M, Starke A, Stöber M, Rehage J (2004) Post surgical development of inflammatory adhesions and reticular function in cows suffering from traumatic reticuloperitonitis. Deutsche Tierarztliche Wochenschrift 111:57-62

Jain NC (1986) Schalm's veterinary hematology, 4th edn. Lea and Febiger, Philadelphia, pp 381-383

Jain NC (1993) Essentials of veterinary hematology. Lea and Febiger, Philadelphia, pp 66-67

Kaneko JJ, Harvey JW, Bruss ML (2008) Clinical biochemistry of domestic animals, sixth ed. Academic, London, pp 117-138

Kennedy DW, Bunting LD (1991) Alterations in ruminal utilization of magnesium and zinc in lambs fed different ratios of concentrate: forage. Int J Vit Nutr Res 61:67-71

Leaf A (1962) The clinical and physiologic significance of the serum sodium concentration. N Engl J Med 267:77-83

Lotscher M, Wilson P, Nguyen S, Kaissling B, Bibber J, Murer H, Levi M (1996) New aspects of adaptation of rat renal Na-Pi contransporter to altertions in dietary phosphate. Kidney Int 49:1012-1018

McDowell LR (1992) Magnesium. In: Minerals in animal nutrition. Academic Press, San Diego. 115-136

Patrick J (1997) Assessment of body potassium stores. Kidney Int $11: 476-490$

Radostits OM, Gay ML, Blood DC, Hinchcliff KW (2007) Veterinary medicine, tenth ed. Baillier Tindall, London, pp 303-311

Rayssiguier Y (1984) Magnesium and disorders associated with magnesium deficiency (in goats). Les maladies de la chevre, colloque international, Niort, France. 28: 411-414

Rose BD (1984) Clinical physiology of acid-base and electrolyte disorders, 2nd edn. McGraw-Hill, New York

Rude RK, Oldham SB (1990) Disorders of magnesium metabolism. In: Cohen RD, Lewis B, Alberti KGM, and Denman AM (eds) The metabolic and molecular basis of acquired disease. Bailliere Tindall, London. 1: 1124-1148

Saxton DR, Seldin DW (1996) Clinical interpretation of laboratory valves. In: Kokko JP, Tannen RL (eds) Fluids and electrolytes. Saunders, Philadelphia, pp 3-62

Scribner BH (1969) Teaching syllabus for the course on fluid and electrolyte balance. University of Washington, School of medicine, Seattle

Silverstein D, Barac-Nieto M, Spitzer A (1996) Mechanism of renal phosphate retention during growth. Kidney Int 49:1023-1026

Smith BP (2009) Large animal internal medicine, 4th edn. Mosby, Maryland Heights

Whitaker DA, Kelly JM, Eayres HF (1998) Use and interpretation of metabolic profiles in dairy cows. Department of Veterinary Clinical Studies, University of Edinburgh, UK 